\title{
Was the Silver Y Moth Autographa gamma (Lepidoptera: Noctuidae: Plusiinae) in South America?
}

\author{
Martha C. Erazo-Moreno ${ }^{1}$, Eduardo Carneiro ${ }^{1} \&$ Alexandre Specht ${ }^{2}$ \\ ${ }^{1}$ Departamento de Zoologia, Universidade Federal do Paraná, Curitiba, Paraná, Brazil \\ ${ }^{2}$ Embrapa Cerrados, Planaltina, Distrito Federal, Brazil \\ Correspondence: Alexandre Specht, Embrapa Cerrados, Rodovia BR 020, Km. 18, Zipcode 73310-970, Postal \\ Box 08223, Distrito Federal, Brazil. Tel: 55-61-3388-9859. E-mail: alexandre.specht@embrapa.br
}

Received: September 23, 2018

Accepted: November 2, 2018

Online Published: January 15, 2019

doi:10.5539/jas.v11n2p132

URL: https://doi.org/10.5539/jas.v11n2p132

\begin{abstract}
In this study we confirmed former records of Autographa gamma in South America by examining four individuals collected in different locations of Brazil and Uruguay. Species identity was established by examining male and female genitalia morphology. Some, but not all, location records are in the vicinity of cities with large seaports used for commercial trades of agricultural goods. Additionally, literature records indicate this species was using local hostplants. Furthermore, addtional repports states that this species had large populations during the end of thirties decade but vanished after that without further justification. Here we discuss aspects related to a possible reintroduction of species in the future as a consequence of the increasing world trade business.
\end{abstract}

Keywords: invasive species, quarantine species, natural extinction sampling and detection, semilooper

\section{Introduction}

The introduction of pest species across continents is one of the main concerns of governmental pest control agencies, due to economic losses caused by alien species (Paini, Sheppard, Cook, De Barro, Worner, \& Thomas 2016). The increasing world globalization and food trade raises the thread of invasions, especially to those countries dependent on agriculture (Early et al., 2016). Despite the worldwide efforts related to monitoring international food trade, recent pest species invasions are still being recorded. This is the case of noctuid species whose larvae defoliates several crop species of great economic importance (Hill \& Gatehouse, 1992). For example, Helicoverpa armigera (Hübner, [1808]) has been recently reported and spread in America (Czepak, Albernaz, Vivan, Guimarães, \& Carvalhais, 2013; Specht, Sosa-Gómez, Paula-Moraes, \& Yano, 2013; Kriticos et al. 2015). Although it was reported in 2013 (Czepack et al., 2013) the examination of specimens deposited in entomological collections in Brazil revealed that $H$. armigera had already been present in Brazil since 2008 (Sosa-Gómez et al., 2016). Similarly, Spodoptera frugiperda (J.E. Smith, 1797) was recently recorded in Africa (Goergen, Kumar, Sankung, Togola, \& Tamò, 2016), already causing severe damages to food production in this continent. These moths are known to develop different resistant strategies to chemical pesticides and transgenic plants, making them very difficult to control in the new habitat (Kergoat et al., 2012).

On the other hand, there are also historical cases when alien species went extinct after reported feeding in crop species outside its natural habitat range (Hoddle, 2006). Such reports deal sometimes with taxonomic problems when species identification is misleading. Thus, precise taxonomical identification of historical invasions is fundamental to estimate the likelihood of these species to reestablish in the same habitat after a new invasion event. In this communication, we confirm the historical records of the presence of silver Y moth Autographa gamma (Linnaeus, 1756) in South America (Biezanko \& Freitas, 1938; Parseval, 1939; Redaelli, 1948; Biezanko, Bertholdi, \& Baucke, 1949; Biezanko, Ruffinelli, \& Carbonell, 1957; Bertholdi \& Biezanko, 1950, 1951; Bertels, 1956; Costa, 1958; A. G. D. A. Silva, Gonçalves, Galvão, Gonçalves, Gomes, N. M. Silva, \& Simoni, 1968; Specht \& Corseuil, 1996) by studying the genitalia of specimens deposited in Brazilian museums.

\section{Method}

Aiming to confirm the literature records of Autographa gamma in South America, we searched for voucher specimens deposited in entomological collections nearby the species presence was originally reported. The scientific collections visited were: CAMB - Coleção Andréj Menschoy Bertels of the Embrapa Clima 
Temperado; DZUP_Coleção Entomológica Pe. Jesus Santiago Moure, MECB-Museu Entomológico Ceslau Biezanko of the Universidade Federal de Pelotas (UFPel); MRGC-Museu Ramiro Gomes Costa of the Fundação Estadual de Pesquisa Agropecuária do Rio Grande do Sul (FEPAGRO), and VOB_Collection of V.O. Becker. After finding specimens similar to A. gamma collected in South America, we dissected and compared male and female genitalia with specimens collected in Europe and Asia.

\section{Results}

After analyzing the moth collection from all these collections, we confirm the presence of four specimens of $A$. gamma deposited in the following Brazilian collections: 1) Penedo/Resende, Rio de Janeiro, Brazil, 7-XI-67, male (VOB); 2) Pelotas, Rio Grande do Sul, Brasil, C. Biezanko det., 16-VI-37, female without abdomen (MECB), 3) Pelotas, Rio Grande do Sul, Brasil, 25-II-1939, C. Biezanko det., female (MRGC); 4) Montevideo, Uruguay, M.A. Monné, no date, male (VOB).

Description: Wingspan length $3.9 \mathrm{~mm}$ in female and $4.1 \mathrm{~mm}$ in males, similarly to specimens found in Europe (Ronkay, Ronkay, \& Behounek, 2008). General pattern of wing markings and coloration is similar on both sexes (Figure 1). The male genitalia present a lamella-shaped valva with a truncated apex. Also, the edeago presents a large spine at the base of the vesica, which distinguishes it from Autographa californica (Speyer, 1875), a sibling species that occurs in North America (Lafontaine \& Poole, 1991). Furthermore, part of vesica clothed by several small spines, besides the leedle-like cortunto. The female genitalia present distinct sclerotizations both in bursa duct and in the anterior lobe of corpus bursae. Both genitalia match with those of other specimens collected in Italy and Belgium (DZUP) and with illustrations provided by Lafontaine and Poole (1991) and Ronkay et al. (2008).

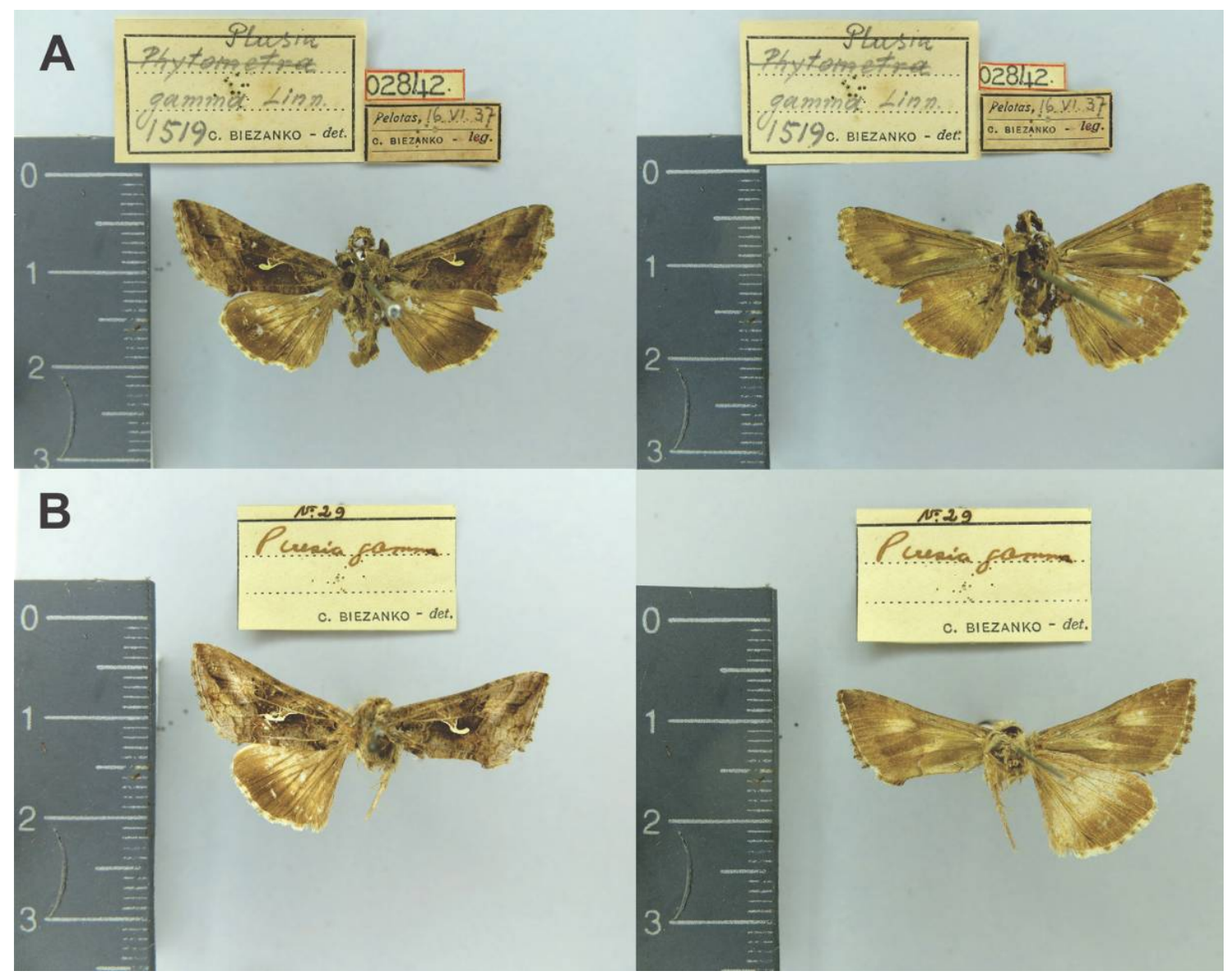

Figure 1. Autographa gamma: A. Female dorsal and ventral view; B. Female dorsal and ventral view 


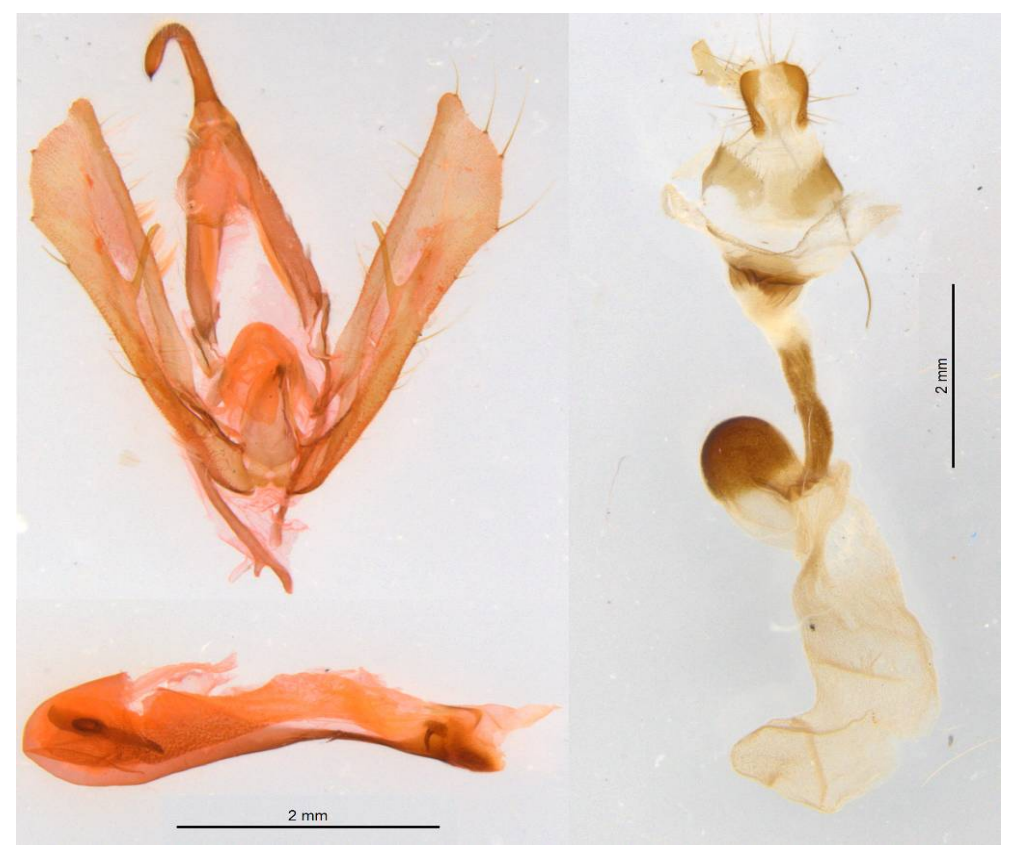

Figure 2. Autographa gamma genitalia: Above left: posterior view of male genitalia; below left: lateral view of edeago; right: posterior view of female genitalia

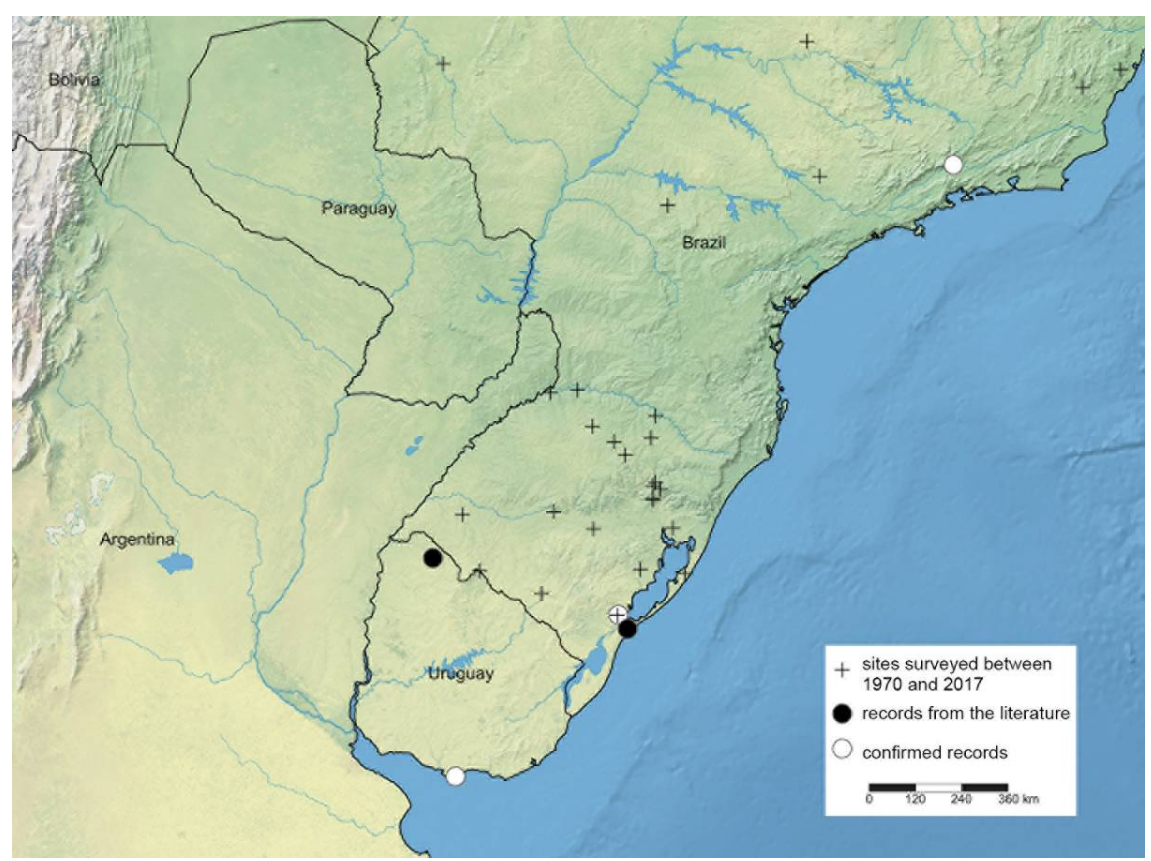

Figure 3. Autographa gamma historical distribution in South America. White spots represent places where specimens has been collected and remain preserved in Brazilian museums; black spots represent places where the literature indicates that specimens collected and crosses represent sites sampled since the 1970s without any record until 2017

\section{Discussion}

The first bibliographical record of A. gamma in South America is that from Biezanko and Freitas (1938), who mentioned it to be an eminent threat to Brazilian agriculture due to several specimens captured in the field. However, since they did not provide genitalia drawings nor a taxonomic description or diagnoses, its true identity was still suspicious. Here, we found several additional evidences to support that A. gamma was present 
in South America, at least in the cities of Rio de Janeiro, Pelotas (Brazil) and Montevideo (Uruguay). In addition to the sites where voucher specimens were found, the literature records it also in Arroio Tres Cruces, Artigas, Uruguay (Biezanko et al., 1957) and in the city of Rio Grande, Rio Grande do Sul, Brazil. Therefore, the species was not only present in South America but also had wide geographical distribution. During our visit at MECB, we found an unpublished manuscript of C. Biezanko reporting detailed information about the species. C. Biezanko mentions in this document that Dr. W. T. M. Forbes, Cornnel, N. Y., USA confirmed himself the identification of Plusia gamma, quoting: "Your Plusia gamma have surprised me very much. They are in fact gamma as you thought, and it must be an introduction from Europe. I have compared the genitalia with specimen I caught in France and also with our northern $P$. californica, which is supposed to be a race of gamma. In fact, yours are true gamma, while californica is a little different". Further, Biezanko mentined that A. gamma was common in Pelotas and in the surrounding areas until de beginning of 1960s.

In Rio Grande do Sul State, Silva et al. (1968) recorded A. gamma larvae feeding on: Apiaceae: Parsley_Petroselinum crispum (Mill.) Nyman ex A.W. Hill; Brassicaceae: Collard—Brassica oleracea L. var. viridis L.; Cabbage—Brassica oleracea var. capitata L.; Chenopodiaceae: Chard—Beta vulgaris L. ssp. cicla (L.) W.D.J. Koch; Beet—Beta vulgaris L.; Spinach—Spinacia oleracea L.; Fabaceae: Bean—Phaseolus vulgaris L.; Pea-Pisum sativum L.; Clover-Trifolium incarnatum L.; Sainfoin-Onobrychis viciifolia Scop.; Serradela-Ornithopus sativus Brot.; Linaceae: Flax-Linum usitatissimum L.; and Solanaceae: Potato-Solanum tuberosum L. Therefore, there is enough evidence to support the species was not only present by occasional records, but certainly established populations in Southern South America during this period. Elsewhere, A. gamma is known as a destructive and migratory insect that feeds on more than 311 plant species throughout Europe and Asia (Noma et al., 2010). Consequently, it is currently included in the quarantine list of the United States under the status of high invasive risk (Noma et al., 2010). In this country, the silver-Y moth has been intercepted in more than 130 imported plants samples, most commonly on cut flowers exported from the Netherlands (USDA-APHIS, 2010) and the possible establishment of this species determined structured surveys of its occurrence using pheromones in approximately 20 US states through the USDA's Cooperative Agricultural Pest Survey (CAPS) program (Zink, Tembrock, Timm, \& Gilligan, 2018).

On the other hand, several evidences suggest its local extinction after the 1970s Biezanko's unpublished appointments reported that the larvae could not be found in the region. Several Noctuid systematical samplings (Figure 3) have been conducted in Southern South America, recording several species of Plusiinae, except for $A$. gamma (Tarragó, Carvalho, \& Link, 1975; Link, 1977; Silveira-Neto, Monteiro, Zucchi, \& Moraes, 1995; Specht \& Corseuil, 2002; Specht, Teston, Di Mare, \& Corseuil, 2005; Zenker, Botton, Teston, \& Specht, 2010; Specht et al., 2013). These samplings were sometimes performed monthly, during more than one year, suggesting that a major collecting effort was taken during the last four decades without any additional record. Intriguingly, $A$. gamma populations are also declining in Netherlands and in the Great Britain (Fox et al., 2013; Ellis, 2016), and the reason justifying this decline is still debated among effects of strong deleterious nitrogen deposits, immigration rates reduction, and global changes (Wallis de Vries \& Van Swayy, 2006; Ellis, 2016).

We are therefore convinced of the extinction of this species due to the bibliographical reports that mention the absence of larvae and adults from the 1970s and recent exhaustive collections throughout the area of occurrence without finding a single specimen. Henceforth, knowing the past occurrence of this species in Brazil allows us to consider an especial carefulness and improvement of control practices of national imported food to avoid its possible reintroduction. Thought we do not know the specific reason why this species has vanished, the amount of records both from deposited specimen and literature between the 30's to the 70's, in distant locations in South America, associated with crop species, suggests that this species is likely to be reintroduced, thus becoming a serious threat to several types of economically agricultural goods (USDA-APHIS, 2010; Zink et al., 2018). Therefore, all southern South American countries that share similar climate and crop species production (such as Brazil, Uruguay and Argentina) should also focus their interception quarantine services on specific species target, once the establishment of noctuid species in a new continent could be followed by a prompt geographical dispersal and population outbreaks (Kriticos et al., 2015; Georgen et al., 2016). A. gamma is known to be a primate migrant in the Palearctic thus ranging practically all parts of Europe including a wide variety of habitats and climate conditions (Ronkay et al., 2008). Therefore, its interception in South America should be carefully monitored once its establishment could generate additional concerns to the food production in the southern part of the continent.

\section{References}

Bertels, A. M. (1956). Entomologia Agrícola Sul-Brasileira. Rio de Janeiro: Serviço de Informação Agrícola, Ministério da Agricultura do Brasil, Série Didática n 16. 
Bertholdi, R. E., \& Biezanko, C. M. (1950). Principais noctuídeos prejudiciais às plantas cultivadas em arredores de Pelotas. Ciência e Cultura, 2(4), 304.

Bertholdi, R. E., \& Biezanko, C. M. (1951). Principais noctuídeos prejudiciais às plantas cultivadas em arredores de Pelotas. Agronomia, 10(4), 235-246.

Biezanko, C. M., \& Freitas, R. G. (1938). Fascículo I. Lepidópteros (Contribuição ao conhecimento da fisiografia do Rio Grande do Sul). Boletim da Escola de Agronomia “Eliseu Maciel”, 25, 1-30.

Biezanko, C. M., Bertholdi, R. E., \& Baucke, O. (1949). Relação dos principais insetos prejudiciais observados nos arredores de Pelotas, nas plantas cultivadas e selvagens. Agros, 2(3), 156-213.

Biezanko, C. M., Ruffinelli, A., \& Carbonell, C. S. (1957). Lepidoptera del Uruguay_Lista anotada de especies. Revista de la Facultad de Agronomía, 46, 1-149.

Costa, R. G. (1958). Alguns insetos e outros pequenos animais que danificam plantas cultivadas no Rio Grande do Sul. Porto Alegre: SIPA-Secretaria de Estado dos Negócios da Agricultura, Série A.

Czepak, C., Albernaz, K. C., Vivan, L. M., Guimarães H. O., \& Carvalhais, T. (2013). First reported occurrence of Helicoverpa armigera (Hübner) (Lepidoptera: Noctuidae) in Brazil. Pesquisa Agropecuária Tropical, 43(1), 110-113. https://doi.org/10.1590/S1983-40632013000100015

Early, R., Bradley, B. A., Dukes, J. S., Lawler, J. J., Olden, J. D., Blumenthal, D. M., ... Tatem, A. J. (2016). Global threats from invasive alien species in the twenty-first century and national response capacities. Nature Communications, 7, 12485. https://doi.org/10.1038/ncomms 12485

Ellis, W. N. (2016). What is going on with the silver Y, Autographa gamma? Entomologische Berichten, 76(1), 21-27.

Fox, R., Oliver T. H., Harrower, C., Parsons, M. S., Thomas, C. D., \& Roy, D. B. (2014). Long-term changes to the frequency of occurrence of British moths are consistent with op-posing and synergistic effects of climate and land-use changes. Journal of Applied Ecology, 51, 949-957. https://doi.org/10.1111/ $1365-2664.12256$

Goergen, G., Kumar, P. L., Sankung, S. B., Togola, A., \& Tamò, M. (2016). First report of outbreaks of the fall armyworm Spodoptera frugiperda (J.E. Smith) (Lepidoptera, Noctuidae), a new alien invasive pest in West and Central Africa. PLoS One, 11, 1-9. https://doi.org/10.1371/journal.pone.0165632

Hill, J. K., \& Gatehouse, G. (1992) Genetic control of the pre-reproductive period in Autographa gamma (L.) (Silver Y moth) (Lepidoptera: Noctuidae). Heredity (Edinb), 69(5), 458-464. https://doi.org/10.1038/ hdy. 1992.150

Hoddle, M. S. (2006). Historical review of control programs for Levuana iridescens (Lepidoptera: Zygaenidae) in Fiji and examination of possible extinction of this moth by Bessa remota (Diptera: Tachinidae). Pacific Science, 60(4), 439-453. https://doi.org/10.1353/psc.2006.0030

Kergoat, G. J., Prowell, D. P., Le, B. P., Mitchell, A., Dumas, P., Clamens, A., ... Silvain, J. (2012). Disentangling dispersal, vicariance and adaptive radiation patterns: a case study using armyworms in the pest genus Spodoptera (Lepidoptera: Noctuidae). Molecular Phylogenetics and Evolution, 65(3), 855-870. https://doi.org/10.1016/j.ympev.2012.08.006

Kriticos, D. J., Ota, N., Hutchison, W. D., Beddow, J., Walsh, T., Tay, W. T. ... Zalucki, M. P. (2015). The potential distribution of invading Helicoverpa armigera in North America: is it just a matter of time? PLoS One, 10, 1-24. https://doi.org/10.1371/journal.pone.0119618

Lafontaine, L., \& Poole, T. (1991). Noctuoidea: Noctuidae (Part), Plusiinae. In R. B. Dominick, et al. (Eds.), The Moths of America North of Mexico, fascicle 25.1. The Wedge Entomological Research Foundation, Washington, D.C.

Link, D. (1977). Abundância relativa de alguns Noctuidae, em armadilha luminosa, em Santa Maria, RS. Revista do Centro de Ciências Rurais, 7(4), 331-351.

Noma, T., Colunga-Garia, M., Brewer, M., Landis, J., Gooch, A., \& Philip, M. (2010). Silver Y moth Autographa gamma. Michigan State University's Invasive Species Factsheets. Retrieved from https:/www.canr.msu. edu/ipm/uploads/files/Forecasting_invasion_risks/silverYMoth.pdf 
Paini, D. R., Sheppard, A. W., Cook, D. C., De Barro, P. J., Worner, S. P., \& Thomas, M. B. (2016). Global threat to agriculture from invasive species. Proceedings of the National Academy of Sciences, 113(27), 7575-7579. https://doi.org/10.1073/pnas.1602205113

Parseval, M. (1939). Pequenas notas entomológicas: Duas lagartas nocivas às plantações de plantas oleaginosas. Revista de Agronomia, Porto Alegre, 3(29), 403-405.

Redaelli, D. C. (1948). Pragas das hortas. Secretaria de Estado dos Negócios da Agricultura, Indústria e Comércio, Porto Alegre, RS, Brasil, Série C.

Ronkay, L., Ronkay, G., \& Behounek, G. A (2008). Taxonomic Atlas of the Eurasian and North African Noctuoidea: Plusiinae I-The Witt Catalogue (Vol. 1). Heterocera Press Ltd., Hungary.

Silva, A. G. D. A., Gonçalves, C. R., Galvão, D. M., Gonçalves, A. J. L., Gomes, J., Silva, N. M., \& Simoni, L. (1968). Quarto catálogo dos insetos que vivem nas plantas do Brasil, seus parasitos e predadores (Tomo 1, Parte 2). Ministério da Agricultura, Rio de Janeiro.

Silveira-Neto, S., Monteiro, R. C., Zucchi, R. A., \& Moraes, R. C. B. (1995). Uso da análise faunística de insetos na avaliação do impacto ambiental. Scientia Agricola, 52(1), 9-15. https://doi.org/10.1590/S0103-9016 1995000100003

Sosa-Gómez, D. R., Specht, A., Paula-Moraes, S. V., Lopes-Lima, A., Yano, S. A. C., Micheli, A., .... Azevedo-Filho, W. S. (2016). Timeline and geographical distribution of Helicoverpa armigera (Hübner) (Lepidoptera, Noctuidae: Heliothinae) in Brazil. Revista Brasileira de Entomologia, 60(1), 101-104. https://doi.org/10.1016/j.rbe.2015.09.008

Specht, A., \& Corseuil, E. (1996). Lista documentada dos noctuídeos (Lepidoptera; Noctuidae) ocorrentes no Rio Grande do Sul, Brasil. Biociências, 4(2), 131-170.

Specht, A., \& Corseuil, E. (2002). Diversidade dos noctuídeos (Lepidoptera, Noctuidae) em Salvador do Sul, RS, Brasil. Revista Brasileira de Zoologia, 19(Suppl. 1), 281-298. https://doi.org/10.1590/S0101-81752002 000500022

Specht, A., Silva, E. J. E., \& Link, D. (2004). Noctuídeos (Lepidoptera, Noctuidae) do Museu Entomológico Ceslau Biezanko, Departamento de Fitossanidade, Faculdade de Agronomia Eliseu Maciel, Universidade Federal de Pelotas, RS. Revista Brasileira de Agrociência, 10(4), 389-409.

Specht, A., Teston, J. A., Di Mare, R. A., \& Corseuil, E. (2005). Noctuídeos (Lepidoptera, Noctuidae) coletados em quatro Áreas Estaduais de Conservação do Rio Grande do Sul, Brasil. Revista Brasileira de Entomologia, 49(1), 130-140. https://doi.org/10.1590/S0085-56262005000100015

Specht, A., Sosa-Gómez, D. R., Paula-Moraes, S. V., \& Yano, S. A. C. (2013). Identificação morfológica e molecular de Helicoverpa armigera (Lepidoptera: Noctuidae) e ampliação de seu registro de ocorrência no Brasil. Pesquisa Agropecuária Brasileira, 48(6), 689-692. https://doi.org/10.1590/S0100-204X20130 00600015

Tarragó, M. F. S., Carvalho, S., \& Link, D. (1975). Levantamento da família Noctuidae, através de armadilhas luminosas, em Santa Maria, RS. Revista Centro Ciências Rurais, 5(2), 125-130.

USDA-APHIS. (2010) Federal Order to prevent the introduction or the dissemination of several harmful pests into the United States, including Helicoverpa armigera (Cotton bollworm), Mamestra brassicae (Cabbage moth), Autographa gamma (Silver-Y moth), on Cut Flowers from the Netherlands. Retrieved from https://www.aphis.usda.gov/import_export/plants/plant_imports/federal_order/downloads/2010/Netherlands CutFlowersRevised.pdf

Wallis de Vries, M. F., \& Van Swaay, C. A. M. (2006). Global warming and excess nitrogen may induce butterfly decline by microclimatic cooling. Global Change Biology, 12, 1620-1626. https://doi.org/10.1111/j.1365-24 86.2006.01202.x

Zenker, M. M., Botton, M., Teston, J. A., \& Specht, A. (2010). Noctuidae moths occurring in grape orchards in Serra Gaúcha, Brazil and their relation to fruit-piercing. Revista Brasileira de Entomologia, 54(2), $288-297$. https://doi.org/10.1590/S0085-56262010000200012

Zink, F. A., Tembrock, L. R. Timm, A. E., \& Gilligan, T. M. (2018). A ddPCR assay for identification of Autographa gamma (Noctuidae: Plusiinae) in bulk trap samples. Journal of Economic Entomology, 111(3), 1490-1495. https://doi.org/10.1093/jee/toy052 


\section{Copyrights}

Copyright for this article is retained by the author(s), with first publication rights granted to the journal.

This is an open-access article distributed under the terms and conditions of the Creative Commons Attribution license (http://creativecommons.org/licenses/by/4.0/). 